\title{
ONTWIKKELINGSTEMPO BINNE BANTOE-GEBIEDE BY AFSONDERLIKE ONTWIKKELING
}

\section{Inleidend}

Wanneer daar vir die deurvoering van 'n proses van ontwikkeling binne die Bantoegebiede of -protektorate van die Unie van Suid-Afrika meer tyd gevra word, is daar geen bygedagte om hier ontwikkeling deur tydsverloop op die langebaan te skuiwe nie. Aanvanklike eise van tydsverloop soos deur die Tomlinson-kommissie en individuele skrywers geprojekteer, is vir die Volkekundige te kort in terme van jare. Die faktore wat ingevolge die ondervinding van die Volkekunde hierdie tydsverloop sal verleng, moet beklemtoon word. Dat die Volkekundige vanweë sy kennis van die werking van hierdie faktore 'n langer tydsverloop vir die deurvoering van 'n proses van ontwikkeling moet aanvra, is nie die gevolg van onwilligheid tot ondersteuning van ontwikkeling in die Bantoegebiede nie, maar juis die resultaat van 'n verantwoordelike siening van die proses van Afsonderlike Ontwikkeling.

Uit die Samevatting van die Verslag van die Kommissie vir die SosioEkonomiese Ontwikkeling van die Bantoe-gebiede binne die Unie van SuidAfrika (U.G. 61/55) of kortweg die Tomlinson-kommissie, blyk die klem wat gelê word op die dringendheid vir ontwikkeling van die Bantoegebiede oorvloediglik. Van hierdie gevolgtrekking en aanbeveling van die Kommissie kan niks afgedoen word nie. Dit is korrek. Tog word dit so gestel dat die dringendheid en die noodsaak van hierdie ontwikkeling alle ander tydsbepalende faktore moet oorheers. Hoewel die Kommissie op p.113 uitdruklik beweer ,ewewig moet behou word tussen die verskillende ontwikkelingsfasette, soos die ekonomiese en die sosiologiese ..." blyk dit tog dat die ontwikkeling van die mense-materiaal binne hierdie gebiede ondergeskik geplaas moet word aan die noodsaak van ekonomiese omvorming. Die klem val baie swaar op die verandering van die lewensomgewing binne hierdie gebiede waarby die mense, of hulle wil of nie, moet aanpas. Op p. 98 stel die Kommissie dit baie duidelik ,,dat die ontwikkeling van die mense-materiaal nie as voorvereiste vir ekonomiese ontwikkeling gestel kan word nie". Individuele skrywers het hierdie gedagte verder uitgebou en onomwonde verklaar dat die tradisionele lewenswyse van die Bantoevolke onversoenbaar is met ekonomiese ontwikkeling. Om hierdie rede moet die tradisionele lewenswyse van die Bantoevolke so snel moontlik platgeslaan word. Die destruksie en desorganisasie van die bestaande lewenspatroon word deur hierdie skrywers dan as voorvereiste gestel vir ontwikkeling. Dit, sê hierdie ekonome, is juis die prys wat betaal moet word vir ontwikkeling. Hierdie verskerpte proses van ekonomiese omvorming moet dan, binne die raamwerk van die aanbevelinge van die Tomlinson-kommissie, binne redelike beperkte tydsverloop plaasvind. Vir die duidelike aanvang van 'n proses van sodanige omvorming het die Tomlinson-kommissie 
'n termyn van tien jaar en 'n globale uitgawe van $104 \frac{1}{2}$ miljoen pond beraam.

Dit is kortliks die prentjie van ekonomiese ontwikkeling en die insig in die tydsverloop wat daarvoor nodig geag word. Dit is dan onmiddellik duidelik dat daar in hierdie uitgangspunte die gevaar aanwesig is dat die desorganisasie wat in die bestaande sosiale struktuur aangebring moet word, so geweldig in omvang sal wees dat dit op volkome vernietiging van die bestaande orde, en gevolglik chaos, sal afstuur. Uit hierdie chaotiese situasie moet daar dan weer nuwe geintegreerde kultuurpatrone ontwikkel. Vir die termyn wat hiervoor in die lewe van volke nodig is, het diegene wat hulle blindstaar op ekonomiese ontwikkeling alleen, geen oog nie. Belangrik egter dat ons besef dat met sodanige chaos daar geen noemenswaardige mensebasis sal oorbly wat die ekonomiese ontwikkeling wat met soveel miljoene ponde gestimuleer is, as 'n gestabiliseerde proses sal kan laat voortduur nie.

Dit is hierdie laaste punt wat die Volkekundige gedwing word om sterk te beklemtoon. Dit is die verpligting wat die Volkekunde wat die mens binne volksverbande, as totaliteit bestudeer, op hom lê. As die Volkekundige hierdie siening moet openbaar, dus hom nie op eensydige ontwikkeling blindstaar nie, en verantwoordelikheid vir sy aanbevelings moet kan aanvaar, dan moet hy beklemtoon dat daar met hierdie proses van ontwikkeling veel stadiger te werk gegaan sal moet word. Dan moet daar gesê word dat 'n gelyktydige ontwikkeling van die mense-materiaal die enigste vaste waarborg sal wees om ekonomiese omvorming 'n stabiele toekoms te gee. Die vermoë van die mens om self te verander en te ontwikkel mag nie in die proses van ekonomiese ontwikkeling verbygesteek word nie.

Ontwikkeling in die bogenoemde sin is vir die Volkekunde nie net blote omgewingsverandering waarby korttermyn aanpassinge gemaak kan word nie. Ontwikkeling is juis 'n volledige verandering van lewenswyse. As mens die saak so sien, is dit onmiddellik duidelik dat nie net een terrein van die lewe geraak word nie. Nie net die ekonomiese sy nie, maar alle fasette van die lewe, ekonomies, sosiaal, polities, juridies en selfs godsdienstig word deur enige beoogde proses van lewensverandering of ontwikkeling geraak. Vir hierdie volledige proses is uiteraard meer tyd nodig as vir die eerste.

Hierdie insig en stelling is nie die eiendom van die Volkekunde alleen nie. Mens vind dit herhaaldelik terug in die uiteensettinge van wetenskaplikes, wat hoewel hulle slegs belangstelling vir 'n besondere faset van die lewe van volke het, tog 'n oog behou vir die uiteindelike totale geheelbeeld. Daatom dat 'n ekonoom in die publikasie van die Organisation for European economic co-operation, (Parys 1951, paragraaf 54) kan verklaar: „While however the existing social structure undoubtedly limits the speed of development, it is at the same time the only solid foundation for the stability of the territory. Any measure, whatever might appear to be its economic or technical justification, which so 
undermines this foundation as to deprive the people of their sense of direction, would delay genuine progress. The greatest care must therefore be exercised in this connection and no attempt must be made to force unduly the pace of development. The conditions of production are thus closely bound up with the structure of society and if economic progress were to be pushed ahead too rapidly in the underdeveloped regions, serious problems might be created by the drastic changes in social structure that would be involved" (Aangehaal deur dr. H. J. J. Reynders in Tydskrif vir Rasse-aangeleenthede, Januarie 1959, p. 48). Van buite die grense van Suid-Afrika dus kom die waarskuwing van 'n ekonoom dat ons ten eerste oog moet hê vir die bewaring van 'n ,solid foundation for stability"; dat ons ten tweede by geleide ontwikkeling nie daartoe moet oorgaan om die mense se ,sense of direction" te verwyder nie, en ten derde dat ons probleme moet verwag as daar te drastiese ",changes in social structure" voorkom. As ons hierdie bevindinge in volkekundige terme wil motiveer moet ons voorts aandag gee aan die volle draagwydte van die begrip kultuur, die betekenis daarvan in die lewe van die individu, en ten slotte die verloop van en bepalende faktore by ' $n$ proses van kultuurverandering of akkulturatiewe situasie.

Vir 'n behandeling van die laaste faset in ons probleemstelling moet ons eers helderheid hê oor die rigting waarin kultuurverandering gaan plaasvind. Sover het ons ligweg oor die begrip ontwikkeling gepraat. Ontwikkeling vir die Bantoegebiede beteken eintlik verwestering van die lewenswyse in mindere of meerdere mate. Dit word allerweë aanvaar dat die beter benutting van die bodemgesteldheid van die Bantoegebiede die invoering van westerse tegnieke en produksiemetodes noodsaaklik maak. Al sou die Bantoevolke hiertoe onwillig wees, sal hulle dit nie kan ontkom nie want die westerse tegniese prestasies is van so 'n oordonderende aard in die moderne wêreld dat afsondering en uitsluiting daarvan net nie moontlik is nie. As die huidige eenvoudige bestaansekonomie binne die Bantoegebiede dan moet verander in 'n gespesialiseerde en gedifferensieerde ekonomiese struktuur, volgens westerse patroon, beteken dit nie net verandering op ekonomiese terrein alleen nie. Dit beteken ook verwestering in mindere of meerdere mate op alle ander terreine van die lewe om met die veranderde ekonomiese struktuur in balans te kom. Nou moet $u$ nie daarin sien dat ek beweer dat ons die Bantoevolke die westerse kultuur present gaan gee nie. Dit kan hierdie volke wel aangebied word, maar hulle moet dit self verwerf. Vir hierdie verwerwingsaksie is tyd nodig. Daarby moet ook verstaan word dat geen eksterne invloed volledig kan voorskryf tot watter mate daar nog van die oorspronklike lewenswyse elemente behoue sal bly nie. Dit berus by die Bantoevolke alleen.

Die volledige beeld van die tydsverloop wat nodig is vir hierdie verwerwingsaksie sal eers sigbaar wees as ons aandag gegee het aan die betekenis van kultuur in die lewe van die individu. 


\section{Kultuur as 'n innerlike eenheid}

Die begrip kultuur omvat in Volkekundige sin veel meer as die blote aanduiding van die fynere skeppingsuitinge van die mens se gees in die vorm van kuns. Die eenvoudigste definisie van die volkekundige begrip kan mens aandui as die volledige lewenswyse van 'n volk. Nie net sy kunsskeppinge of literêre prestasies nie, maar die volle lewe. Anders gestel sou 'n mens kon sê dat die lewenswyse van 'n volk, sy kultuur, die resultaat vorm van sy aanpassings aan sy omgewing ooreenkomstig sy aard. Dit is egter nie die volle beeld nie daar mens moet onthou dat die skeppinge van die mens ook vir hom omgewingsinvloede vorm. In sekere sin pas die mens ook dus sy omgewing by hom aan. Indien ons egter konsentreer op die eerste, naamlik aanpassing aan omgewing, beteken dit byvoorbeeld dat die mens as fisies-biologiese wese teenoor die eise van die fisies-geografiese omgewing te staan kom. Om hierdie omgewing te kan benut en homself daarin te kan handhaaf bring die mens skeppinge tot stand wat in sy volle vorm die ekonomiese struktuur en tegnologiese vaardighede van die verskillende volke verteenwoordig. Die sprong van die skeppende individu na volkseenhede is nie groot nie want die mens leef nie as individu alleen nie maar in groeps- of volksverbande. Die mens as individu kry eers volle sin en betekenis wanneer hy saam met ander en tussen ander is. Die hooggeroemde waarde van die enkeling is vir die volkekundige feitlik 'n filosofiese abstraksie want juis uit die aanpassing van individue aan ander, aan die sosiale omgewing kom die sosiale organisasie van volke tot stand. Dit is so in die lewe van alle volke op aarde dat mense oor 'n lang periode binne dieselfde vaderland aan mekaar vasgroei op die suiwer biologiese maar ook op die geestelike terrein; dat daar gaandeweg 'n gemeenskaplike sienswyse oor sake opgebou word, gemeenskaplike ideale en aspirasies en taal kenbaar word en so mettertyd 'n volkseenheid gevorm word met 'n eie aard en karakter, met 'n eie lewenswyse of kultuur. Binne die Suid-Afrikaanse verband en ten opsigte van die Bantoevolke wat bestaan beteken dit dat elkeen sy eie, onderling verskillende lewenswyse en taal besit. Indien hierdie lewenswyses vandag verskil moet ons verwag dat die veranderinge wat in hierdie kulture mag plaasvind onder westerse invloed steeds elemente van die oorspronklike verskeidenheid, veral op taalgebied, sal laat voortduur. Dit kan nie anders nie. Hoewel ons onder westerse volke 'n basiese ooreenkoms aantref, onderskei ons tog nog onder andere Britse, Franse, Duitse en Hollandse volkseenhede.

Ondanks die verkeidenheid wat daar aan volke en kulture op die wêreld kenbaar is, vertoon die lewenswyse van volke tog sekere algemene ooreenstemminge. Daar is in elke kultuur dieselfde fasette of onderafdelings wat vanuit bepaalde belangstellingsvelde belig kan word. Ons onderskei so naas andere 'n sosiale, politieke, ekonomiese, tegnologiese, godsdienstige en regs- en taalaspek. Vir baie geesteswetenskaplikes wat uit die westerse orde bepaalde van hierdie fasette bestudeer, bly die 
vlakke van belangstelling geskeie. Nou is dit juis die taak van die Volkekunde om te beklemtoon dat hierdie vlakke nie vollediglik skeibaar is nie en dat daar juis 'n onderlinge gebondenheid tussen die fasette van een kultuur of lewenswyse bestaan. Hierdie onderlinge gebondenheid is eerstens kousaal en tweedens harmonies van aard. Uitgaande van blote tegniese kennis waardeur die ontginningswyse van die bodemgesteldheid bepaal word, word die digtheid van die bevolking voorgeskryf. By hoë bevolkingsdigtheid moet 'n ingewikkelde sosiale struktuur verwag word. 'n Ingewikkelde sosiale struktuur vereis 'n deeglik geordende politieke struktuur en 'n duidelik omlynde regsisteem wat verhoudinge binne die sosiale eenheid waarborg. Uitgaande dus van die tegnologie beland mens deur oorsaaklike verband op die politieke en regsterrein. Ten opsigte van die harmonies gekoppeldheid die volgende: Indien mens, soos by die Bantoevolke, 'n sosiale struktuur aantref wat gekenmerk word deur senioriteitserkenning op grond van afkoms en verwantskap, dan sal die politieke orde dit ook vertoon angesien posisies van sosiale aansien verbindbaar word met die reg van gesagsuitoefening .Op godsdienstige terrein moet mens dan nie verbaas wees as die tradisionele voorvaderdiens met dieselfde senioriteitsbegrippe deurspek is nie. Selfs die priesterlike handelings word gereserveer vir die sosiaal hooggeborenes. Op ekonomiese terrein werk die harmonie deur in die vorm van 'n kommune besitstelsel oor grond en 'n hoë mate van mededeelsaamheid onder verwante.

Dit volg dus logies dat as die tegnologiese basis van die lewenswyse ingewikkelder word sal veranderings nie net op ekonomiese terrein plaasvind nie, maar ook in die volledige samelewingsordening. Dit volg ewe logies dat as die ekonomiese struktuur verwester, gaan daardie invloed harmonies deurwerk na die ander lewensterreine. As die verandering op ekonomiese terrein drasties is, soos verwag kan word by die direkte botsing tussen die westers georiënteerde individualisme en die kommune begrip van die Bantoevolke, gaan daardie drastiese verandering harmonies deurwerk. As die sosiale ordening dan drasties moet verander, moet mens verval en vernietiging van baie wat bekend is verwag. So ook is verval op die politieke terrein en 'n algemene vermindering van die betekenis van etiese begrippe wat uit die godsdiens gefundeer is, te verwagte. Daarmee is die ,solid foundation for stability”, waarvan ons vroeër gepraat het, aangetas. Die termyn wat vir die stadige harmoniese deurwerking van die westerse invloed nodig is, is dan verstaanbaar, veel langer as dié wat vir blote ekonomiese ontwikkeling in westerse rigting nodig is. Die tempo waarteen volledige verandering kan plaasvind word dus inherent bepaal deur die feit dat verandering op ekonomiese terrein die verandering op ander lewensterreine moet saamsleep. Dit vereis dan geen wysgerige insig om te besef dat te snelle verwestering op ekonomiese terrein sodanige chaos op die ander lewensterreine sal veroorsaak dat die „solid foundation for stability" wat vir ware ontwikkeling nodig is, vernietig word nie. Die onderlinge gebondenheid van die verskillende 
lewensfasette van die gehele kultuur maan dus tot versigtigheid by die bepaling van die tempo waarteen enige verandering gelei word.

\section{Kultuur en die persoonlikheidstruktuur}

Die volle implikasie van lewensverandering spreek egter eers na betragting van die betekenis van kultuur in die lewe van die individu. Elke mens is by geboorte reeds lid van 'n bepaalde volk. Oor hierdie lidmaatskap is daar geen selfstandige keuse nie. Na geboorte volg 'n lang proses van opvoeding en inskerping van die voorskrifte van die lewenswyse waarin die opgroeiende individu homself moet inpas. Langs hierdie weg word die individu gevorm tot 'n skakel in die ketting van die kultuurdraers van daardie volk. Hierdie ketting of lewenslyn se aard is bepaal uit die tradisie van die verlede en is vanuit daardie tradisie, deur die toevoeging van nuwe skakels, gerig op voortsetting in die toekoms. Die proses van hierdie inpassing van individue strek dus oor generasies heen en is ' $n$ nimmer eindigende proses. Die aard van die inskerping van lewensvoorskrifte is nie vergelykbaar met westerse skool-opleiding nie. Dit is in wese die vorming van persoonlikhede ooreenkomstig die voorskrifte van die besondere kultuur. Van kleins af word die moets en moenies van die lewenswyse by die kinders tuisgebring. Wanneer volwassenheid bereik is, het hierdie uiterlike gedragsvoorskrifte innerlike persoonlikheidsrigsnoere geword sodat beperkings op handelingsvryhede as normaal beskou en sonder murmurering uitgeleef word. Die voorwaardes vir korrekte lewenswyse het persoonlikheidskenmerke geword. In werklikheid beteken die vaste lewenspatroon waaraan alle opgroeiende individue geleer word om te voldoen, dat alle volkslede 'n onomskrewe enerse geladenheid in hulle persoonlikhede bekom. Dit beteken verder dat daar 'n minimum van enersheid van denke tussen volkslede bestaan waardeur die optrede van ander lede van die volk tot op sekere hoogtes voorspelbaar word en so 'n harmoniese samelewing waarborg.

Dit is dan duidelik dat as daar binne kort periode 'n volledige kultuurverandering moet intree waardeur as ' $t$ ware die bestaande lewenslyn van 'n volk geknip word, daar nie net verandering van uiterlike gedrag sal voorkom nie, maar in wese ook omvorming van persoonlikheidstruktuur, omvorming van ,manier van dink”. Die normale proses by die ervaring van vreemde kultuurinvloede van buite is dat die ou en bekende rigsnoere gebruik word om aanpassinge by die nuwe omstandighede te maak om te waak teen die algehele verbreking van die lewenslyn wat vanuit die verlede stabiliteit in die hede verskaf. Die vreemde gedagtes en kennis word dus ingepas by die bestaande orde. Tot tyd en wyl hierdie vreemde invloede egter so aangepas is aan die bekende lewensorde, tot tyd en wyl die vreemde invloed deur aanpassing versoen is met die inhoud van bestaande persoonlikheidstuktuur, bestaan daar by die lede van die volk in die minimum ' $n$ bepaalde persoonlikheidsonewewigtigheid en in die maksimum persoonlikheidschaos. Dié van u wat kennis dra van die bewustelike en verstandelike inspanning om jou van 'n 
vreemde taal in ' $n$ vreemde land te bedien of an die inspanning om in 'n vreemde land skielik aan 'n ander kant van die pad te ry as die waaraan $u$ gewoond is, sal verstaan wat ons hier bedoel. Daar is 'n tussenperiode van verstandelike heroriëntering tot die eise van die vreemde situasie weer spontane en natuurlike en korrekte reaksies by die individu ontlok. Dieselfde proses werk wanneer die Christelike Boodskap deur 'n heiden anvaar word. Dis nuwe invloede, dis vreemd, dit bring 'n omvorming in die persoonlikheid mee. Die individu is gedurig by homself in 'n keusestryd tussen die voorskrifte van die ou en die nuwe orde. Tot tyd en wyl hierdie invloed verwerk is, is hy nie 'n volledige en ,heel" mens nie.

As dit dan nou die betekenis van kultuurverandering op die terrein van die persoonlikheidstruktuur en karakterstabiliteit is, dan moet ons kan verstaan dat as die eise wat vir verandering gestel word, te groot is, te snelle verandering verwag; as die mense soos visse uit die water voel, aan die eise van verandering nie kan voldoen nie hoewel die verandering onverbiddelik voortsnel, dan word daar persoonlikheidschaos, verwarde denke en verwarde mense geskep.

Die moontlikheid vir die skepping van hierdie innerlike chaos is juis daar aanwesig waar 'n direkte botsing tussen die riglyne van verskillende lewenswyses verwag kan word. Mens moet dit dus veronderstel en verwag by ' $n$ direkte botsing tussen die kommune begrip van die Bantoevolke en die individualistiese houding van die westerse lewenswyse. Mens moet dit verwag wanneer snelle ommeswaai vereis word van 'n sosiale orde gebaseer op senioriteitserkenning vanweë geboorte alleen en erkenning van meerderes slegs volgens rykdom, geleerdheid en bekwaamheid soos in die westerse lewenswyse bekend is. Die uiterstes waartussen hier, by snelle verandering, 'n kompromis vereis word, is te geweldig om binne die bestaande persoonlikheidstruktuur gemaklik verwerk te word. En dit is waarteen die ekonoom waarsku wanneer hy vra dat ons nie mense hulle sin vir rigting, hulle "sense of direction", moet laat verloor nie. Vir die omordening wat deur hierdie botsende lewensbeginsels vereis word, is ' $n$ baie lang tyd nodig -'n stadiger tempo as wat blote tegnologiese en ekonomiese verandering vereis. En let wel! $\mathrm{U}$ kan daardie tempo nie buite die beperking wat die mense-materiaal self stel, verhaas nie. Dit is so vir alle situasies op aarde waar daar kultuurverandering plaasvind en die probleme waarvan ons hier bo melding gemaak het, is sommige van die wat die ekonome in gedagte het wanneer hulle kortweg waarsku teen probleme wat sal volg by te drastiese ,"changes in social structure". Sover is die saak nog te eenvoudig gestel.

\section{Die proses van akkulturasie}

Wanneer ons die volledige werking van 'n proses van kultuurverandering in oënskou neem en steeds onthou dat ons reeds beklemtoon het dat verandering op een terrein verandering op ander terreine sal 
meebring, asook dat verandering probleme in persoonlikheidsaanpassing meebring, word al die faktore wat van tydbepalende aard is, duidelik.

By prosesse van kultuurverandering kan ons eerstens 'n eenvoudige situasie onderskei waar die slegs gaan om oordrag van kultuurelemente. Tweedens kan ons 'n komplekse situasie onderskei waar dit nodig word vir mense, draers van die aanrakende kulture, om tot 'n nuwe volkseenheid te geraak en derdens bly daar steeds kritieke situasies van kultuurverandering waar verskeie faktore wat hierdie proses van verandering kan strem of bevorder, werksaam is.

Binne 'n eenvoudige proses van kultuurverandering gaan dit in hoofsaak oor wat ons reeds bespreek het, naamlik die gestadige inspanning van volksvreemde kennis en -gebruike by die bestaande lewensorde. Die termyn wat vir hierdie proses nodig is, strek gewoonlik oor generasies heen. Die eerste generasie ontvang die vreemde element en verwerk dit onvolledig. Wanneer hulle dit aan hulle kinders moet oordra geskied dit onvolledig omdat dit nog nie deel is van die bekende lewensorde nie. Die tweede generasie ontvang die invloed onvolledig, is self aan hierdie invloed onderhewig, indien dit voortduur, en dra dit in vollediger mate aan hulle kinders oor. En eers hierdie derde generasie, wat self aan die vreemde invloed onderhewig moet bly, is in staat om dit vollediglik aan hulle kinders oor te dra.

Eers teen die einde van die derde generasie het die vreemde invloed, indien dit nie te ernstig in botsing met die vroeëre orde is nie, volledig deel van hulle lewenswyse geword. Hierdie tydsverloop oor drie generasies is nie arbitrêr vasgestel nie. Dit is bewysbaar uit die ondervinding van immigrasie na Amerika (Vgl. D. A. F. Walter: Race and Culture Relations 1952, p. 52 en verder). Dat die proses van kultuurverandering minstens sodanige tydsverloop veronderstel is verstaanbaar aangesien ons gewys het op die verband met persoonlikheidsvorming wat moet saamgaan met verandering in lewenswyse. Tot tyd en wyl die derde generasie dus aangebreek het moet ons besef dat daar in die feitelike toestand steeds onewewigtige persoonlikhede aanwesig sal wees. Drie generasies is en bly die ware minimum tydsverloop wat nodig is vir eenvoudige kultuurverandering. Dat daar individue is by wie hierdie proses vinniger kan plaasvind weet ons ook, maar ons belangstelling is hier vir groepe van mense, volke as eenhede by wie verandering plaasvind. Daarvoor is ' $n$ langer termyn nodig as vir begaafde enkelinge wat die inherente aanpassingsvermoë het om die proses sneller te deurloop. Die termyn wat ons geskets het is die minimum wat nie alleen in Suid-Afrika nie maar orals elders in Afrika verwag moet word mits daar geen vertragende faktore werksaam is nie. En daar is.

Kultuur of lewenswyse is as abstraksie sinneloos daar ons in werklikheid met mense, die draers van hierdie lewenswyses te doen het. Kultuur kan nie losgedink word van die draers daarvan nie. Wanneer daar dan sprake is van twee kulture wat mekaar beïnvloed tree die draers ook in aanraking. Wanneer kultuurelemente uit die vreemde ontvang 
word, word die draers gewoonlik daarmee saam ontvang. Wanneer daar dan van sodanige inpassing van elemente sowel as die draers daarvan in die eie kultuur sprake is, kan ons die veranderingsituasie as kompleks beskrywe. So 'n komplekse situasie bereik normaalweg sy voleinding, indien daar geen stremmende faktore werk nie, wanneer die draers van die eie en die vreemde kultuur sodanig met mekaar gemenesaak gemaak het dat hulle nie meer as vreemdelinge vir mekaar kenbaar is nie. Hier gaan dit dus nie alleen om kulturele inpassing nie, maar ook om biologiese inpassing. Volledige ondertrouing tussen die draers van albei kulture word allerweë aanvaar as die eindstadium van hierdie komplekse situasie van kultuurverandering. Net soos daar persoonlikheidsaanpassinge nodig is by blote kultuurverandering by die eie volk so moet die vreemdelinge ook persoonlikheidsaanpassinge maak om assimileerbaar te word binne die geledere van die ontvangende volksgroep. Tot tyd en wyl hierdie wedersydse aanpassinge gemaak is bestaan daar in die hele volkstruktuur ' $n$ mate van onewewigtigheid, bestaan daar sommige halfvreemde lede op wie nie tot dieselfde mate as lede van die ou garde peil getrek kan word nie.

Die onewewigtigheid waarvan hier sprake is duur so lank as wat die vreemdelinge sosiaal sigbaar bly binne die totale eenheid; solank hulle kenbaar bly aan kleredrag of spraak. Die volledige inpassing van sulke vreemde elemente duur heelwat langer as die bogenoemde drie-generasie patroon. Vir die Suid-Afrikaanse situasie moet mens onmiddellik dan vra wie sal wie absorbeer. Sal die Bantoevolke die Blanke volkseenheid absorbeer of andersom. Dat die Suid-Afrikaanse situasie nog nie as van komplekse aard beskrywe kan word nie, dat daar nog nie wedersydse bloedvermenging op groot skaal plaasgevind het nie, is eintlik teenstryding met die analogie vanuit kultuurverandering situasies elders op die wêreld. Dit is die gevolg van faktore wat sodanig werksaam is dat ons die toestand as 'n kritieke situasie van kultuuraanraking moet beskryf.

Wanneer daar in 'n eenvoudige of komplekse situasie van kultuuraanraking enige van die volgende faktore werksaam is, noem ons die situasie kritiek omdat die faktore die tydsverloop van die proses van verandering ernstig kan verleng.

Die eerste faktor is verskil in getalle. As die lede van 'n klein volkie vind dat hulle oordonder word deur die invloed wat van groot getalle vreemdelinge, met wie hulle in anraking is, uitstraal, dan is die normale proses dat die wat minder in getal is hulle geledere sluit. Dat daar poging aangewend word om na binne te leef. Dat daar 'n hoë waarde aan die nalewing van die verminkte eie kultuur geheg word om langs hierdie weg die geweldige invloed wat dreig om die eie lewenswyse te vernietig, te probeer afwater en die invloed daarvan teen 'n stadiger tempo te laat werk. Die werking van hierdie faktor is nie vir ons in Suid-Afrika vreemd nie. Ons ken die geweldige invloed vanuit die kamp van die Britse kultuur en die reaksies teen hierdie invloed. Ten opsigte van die Bantoe volke 
werk hierdie faktor nie. Indien daar egter ooit sprake kom van die invoeging van die Blanke volkseenheid by die Bantoevolke moet ons nie die tydsverlengende werking van hierdie faktor onderskat nie.

Die tweede faktor is die van verskil in kultuurdistansie. Dit vind soms plaas dat kulture waarvan die innerlike aard uiteenlopend is en grootliks met mekaar verskil, in aanraking kom. Let wel: Hier is nie sprake van 'n mindere of meerdere waarde nie, maar slegs van 'n duidelike andersoortigheid soos tussen die lewenstipes van die Boesman- en Bantoevolke of die van die Fransman en Sjinees. As sodanige kulture of die draers daarvan in aanraking tree en 'n sintese daartussen moet bewerkstellig word, sodat uiteindelik 'n harmonies saamgegroeide eenheid tot stand moet kom, is die tydsverloop haas oneindig lank. Dit is so, eerstens vanweë die langdurige sosiale sigbaarheid van die draers van die kulture vir mekaar. Of as daar van vermenging van mense nie sprake is nie, vanweë die geweldige persoonlikheidsomvorming wat moet plaasvind. Ten opsigte van die Bantoe in Suid-Afrika werk hierdie faktor, soos ons reeds terloops gewys het, die deurvoering van 'n stadige tempo van verwestering in die hand en voorspel 'n termyn wat veel langer sal duur as die drie-generasie-patroon van 'n eenvoudige situasie.

By die beklemtoning van die kulturele distansie tussen die lewenswyse van die Bantoevolke en die westerse volke is dit nie die gedagte om selfs by implikasie te beweer dat die Bantoevolke nie in staat is om die westerse lewenswyse deelagtig te word nie. Wat wel beklemtoon word, is dat die aard van die Bantoevolke se lewenswyse 'n inherente beperking vorm vir vinnige en snelle verwestering. Die kulturele distansie is te groot. Ten opsigte van hierdie punt moes ons nog wys op 'n moontlikheid wat tans nog in die Volkekunde nie bewysbaar is nie, nl. die moontlikheid dat daar wel situasies kan voorkom waar volke 'n onvermoë tot aanpassing en verandering openbaar. Voor die koms van die blankes in Suidelike Afrika het ons onder andere die noue aanraking gevind van Boesmans en Bantoes. Ondanks die feit dat die ekonomiese prestasies, tegnologiese diversiteit en benuttingswyse van bodemgesteldheid van die Bantoe baie ingewikkelder as die van die Boesmans was, het die Boesmanvolke nie verbantoe nie. By die aanraking van die Bantoe en Boesman lewenstipes, wat basies verskillend is, het die Boesmanvolke verkies om Boesmans te bly. Ondanks die moontlikheid dat ons hier met suiwer konserwatisme te doen het, moet die moontlikheid van onaanpasbaarheid nie uit die oog verloor word nie. As ons hierdie moontlikheid ten opsigte van die Bantoevolke ondersoek moet ons verklaar dat die Bantoevolke, soos ons hulle ken, inherent die vermoë besit om die lewenswyse van die blankes oor te neem. Maar dit mag ook so wees dat ons onder hulle mense sal vind wat 'n onvermoë sal openbaar om hulle geestelik in te stel op die eise wat 'n westerse lewenswyse vereis. Indien daar dan so 'n werklikheid bestaan, iets wat tans nie voorspelbaar of wetenskaplik bewysbaar is nie, moet die implikasie van so 'n toestand by snelle verwestering onder oë gehou word. 
Die derde faktor wat aanleiding tot 'n kritieke toestand van kultuurverandering kan gee is die moontlikheid van die stremming of bevordering van verandering deur faktore wat in die geskiedenis wortel. Wanneer die draers van die twee kulture wat deur aanraking tot 'n nuwe sintese moet groei, van te vore vyande was, mekaar van oor die wapen beskou het, dan bly hierdie struweling uit die geskiedenis nog lank tussen hulle staan. Die termyn wat nodig is om hierdie faktor wat vertraging van samegroeiing in die hand werk, uit te wis, strek oor generasies. U kan uself indink watter tydsverloop nodig sou wees om een volk uit die bestaande Britse en Duitse eenhede te vorm. Dit is byvoorbeeld hierdie faktor wat deur sy werking 'n stremming plaas of die volledige samegroeiing van Brit en Afrikaner in Suid-Afrika. Dit is ook hierdie faktor wat tans in die Belgiese Kongo opnuut oorlogstoestande in die hand werk en samegroeiing vertraag. Hoewel dit nie allerweë besef word nie is hierdie faktor een van die wat in die huidige tyd die samegroeiing van die verskillende Bantoe volke tot een geheel vertraag. Dit is hierdie faktor wat, indien Blank en Bantoe in Suid-Afrika tot samegroeiing geneig sou wees, 'n ernstige vertraging in die tydsverloop wat daarvoor nodig sou wees, sal veroorsaak.

Die vierde faktor wat in hierdie verband in gedagte gehou moet word, is verskil in rasse-aanhorigheid. Tot sover is die woord ras met opset nie gebruik nie. 'n Ras is 'n suiwer fisies-biologiese begrip, as dit in enige ander verband gebruik word, word daar gefouteer. Daar is dus nie so iets soos 'n Afrikaner-ras nie buiten wanneer mens van beeste praat. Daar is ook nie so iets soos 'n Engelse ras nie. Daar is wel Afrikaner of Engelse volkseenhede. Waar ons dan van rasseverskil praat word die feit dat verskil in fisiese voorkoms 'n probleemfaktor word wanneer draers van kulture wat in aanraking is, moet saamgroei, bedoel. Dit gaan hier om die beklemtoning van kulturele andersoortigheid deur gelyktydige verskil in fisiese tipe. Indien 'n aantal mense uit Swede en ander uit die Suide van Italië tot eenwording verplig word vanweë noue aanraking, dan bly die een vir die ander sigbaar as van vreemde herkoms totdat daar sodanige mate van ondertrouing plaasgevind het dat die oorspronklike verskille met hulle vreemdsoortige assosiasie uitgewis is. Rasse-aanhorigheid kan nie soos taal en lewenswyse oor die verloop van drie generasies afgelê word nie. Dit kan alleen deur ondertrouing oor 'n baie lang periode uitgewis word en solank dit herkenbaar is, bly die een groep vir die ander sosiaal sigbaar en werk dit vertraging van kulturele en fisiese eenwording in die hand.

Hoe lank vir hierdie proses van biologiese eenwording werklik nodig is, kan nie bepaal word nie. As mens egter besef dat die geringe getal negers in Amerika nog nie binne die magtige bevolkingsgetalle van die Verenigde State oor 'n termyn van 300 jaar verwerk is nie en dat die faktore van werklike kultuurverskil, getalsoorwig van negers sowel as geskiedkundige faktore nie werk nie, dan moet almal saamstem dat 
ons hier met 'n ernstige vertragende faktor by samegroeiing van mense te doen het.

Die betekenis van rasseverskil is egter nog nie uitgeput nie. Binne elke kultuur bestaan daar kultureel-bepaalde standaarde van mooi en lelik, van optimum en mindere geskiktheid by die keuse van 'n lewensmaat. Dit wat volledig vreemd is aan die eie volksgroep, dit wat fisies aan ander rasse behoort, beklee 'n baie lae plek op hierdie standaardskaal. Dit gaan nie hier om meerdere of minderwaardigheid nie maar om andersheid. As dit dan so is beteken die samegroeiing van mense van verskillende rassegroepe in die eerste plek ' $n$ verandering in hierdie kultureel-bepaalde skaal van mate van fisiese en geestelike aantreklikheid.

Ten opsigte van die Bantoevolke as eenheid genome moet ons erken dat hierdie faktor geen rol speel ten opsigte van die tempo van verwestering wat plaasvind nie. Behalwe in soverre as die strewe om te verwester 'n gretige mark skep vir preparate wat voorgee om velkleur ligter te maak en kroeshare styl! Wanneer ons later egter die moontlikheid van samegroeiing van Blank en Bantoevolke hier te lande ondersoek, word dit onmiddellik van belang.

Die vyfde en laaste faktor wat 'n kritieke situasie van kultuurverandering by eenvoudige of komplekse omstandighede kan skep, hang saam met sielkundige geneigdhede. Hieronder kan ons 'n verskeidenheid noem maar sal met enkeles moet volstaan.

Wanneer daar by die draers van een kultuur die begeerte bestaan om die vreemde deelagtig te word, word die proses van oorname en kutuurverandering daardeur bevorder en aangehelp. Enige gevoel van konserwatisme en 'n geneigdheid om die eie te probeer behou sal die proses vertraag. Hier het ons vir die eerste keer te doen met die begrippe van mindere en meerdere waarde. As ek 'n begeerte sou hê om Engelsman te word dan ag ek die lewenswyse wat ek tans deelagtig is minder geskik in vergelyking met die van die Brit. As daar, soos vroeër in Holland, die strewe en begeerte bestaan om Frans te word, dan is daar 'n gevoel van minderwaardigheid by die Hollanders teenoor die Franse lewenswyse. Hierdie faktor van eie minderwaardigheidsgevoel teenoor die magtige prestasie van die westerse tegnologie is beslis in Suid-Afrika werksaam onder die Bantoe. Dat hierdie feit daartoe aanleiding gee dat die Blankes in Suid-Afrika hulle meerderwaardig bo die Bantoevolke reken, berus dan nie op rasse-vooroordeel nie maar op goeie oordeel, daar enige westerling die Bantoe-individu wat na verwestering strewe volgens die norm van verwestering baie ver voor is. Van al die faktore wat ons noem wat binne kritieke situasies van kultuurverandering werksaam is, is hierdie die enigste wat die verloop van die proses kan verhaas. Daar dit onder die Bantoevolke werksaam is moet ons versigtig wees om nie die proses van verwestering selfs vinniger as die gretigheid om die meerderwaardige te aanvaar, aan te dryf nie.

Algemeen gesproke moet ons uit die praktyk die bewering maak dat die basiese termyn vir eenvoudige kultuurverandering by volkseenhede 
ongeveer drie generasies is. Waar komplekse toestande heers, waar vreemdelinge, sowel as vreemde kultuur-elemente ingepas moet word, word die termyn baie langer. Wanneer daar egter enige van die vyf bogenoemde faktore werksaam is waardeur ons die akkulturatiewe situasie as kritiek aanmerk, word die termyn wat nodig is vir verandering oneindig verleng. Van al die faktore wat ons genoem het, is vir 'n beleid van ontwikkeling van die Bantoegebiede slegs dié van verskil in kultuurstand wesentlik van belang. Die moeilik oorbrugbare wesensverskil tussen die Bantoe-en Westerse kulture gaan die volledige proses van ontwikkeling oor 'n veel langer termyn as drie generasies laat voortduur.

\section{Afsonderlike ontwikkeling ' $n$ vereiste in Suid-Afrika}

Die ontwikkeling of verwestering van die Bantoevolke word in SuidAfrika as afsonderlike ontwikkeling beskryf. Daarvoor bestaan baie goeie redes.

Indien mens die snelste proses van verwestering met die hoogste moontlike waarborg van stabiliteit en sukses vir die Bantoevolke wil bewerkstelling, moet sake so gereël word dat Blank en Bantoe in hierdie land deelgenote word in een groot venootskap waarin die einddoel van maksimum benutting van bodempotensiaal deur almal hoog genoeg geag word om die ongemak van 'n proses van geestelike en biologiese gelykmaking tussen Blank en Bantoe as van mindere belang te beskou. Ons sê met opset geestelike gelykmaking omdat daar dan geen waarborg vir die behoud of verwerwing van die volle westerse lewenswyse is nie. Ongelukkig het ons egter in Suid-Afrika en elders in Afrika nie met 'n vormlose Bantoemassa te doen wat slegs die dryfvere van bevrediging van ekonomiese behoeftes ken nie. Ons het met volke te doen, tussen wie daar op taalkundige gebied en ten opsigte van die algemene lewenswyse ernstige verskille bestaan. Enige proses van verbinding met die Blankes en samegroeiing tot een volk sou die verplettering van bestaande verskillende volksbewussyns onder die Bantoe en die lydsame en geduldige opgang in 'n nuwe eenheid veronderstel. So iets hou nie rekening met die geskiedenis van verhoudings tussen hierdie volke in die huidige tyd nie.

As ' $n$ verdere feitelike gegewe bestaan daar in Suid-Afrika nie een rormlose Blanke setlaardom wat enkel om ekonomiese selfverryking die land betrek het en hier bly woon het nie. Ons het in Suid-Afrika te doen met 'n Blanke volkseenheid waarin die Afrikaner-element die swaartepunt uitmaak en waartoe daar 'n verskeidenheid van vreemde groepe toegevoeg is. Die kultuur van hierdie volk is, hoewel westers, aan die bodem van Suid-Afrika gebonde. Sy taal en lewenswyse is Afrikaans hoewel gekoppel met die bakermat Europa. Die ontwikkeling van hierdie Afrikaanse volk oor 'n periode van 300 jaar is iets wat die wetenskap nie kan verklaar nie. Dit is 'n moderne wonder wat plaasgevind het deur oorwinning van en in stryd met alle faktore wat aktief werksaam was om samegroeiing met inheemse groepe te bevorder. Die belangrikste oorsaak vir hierdie gebeure is die geweldige verskil in kultuurstand 
tussen die inheemse volksoorte en die Blanke koloniste gewees. Die bestaan van 'n Afrikaanse volk word des te merkwaardiger as ons in gedagte hou dat hy vir 150 jaar van sy bestaan sy kulturele erfenis moes bewaar in die aangesig van die Engelse taal en lewenswyse wat uiteindelik medebestaansreg in Suid-Afrika verwerf het.

Indien ons dan die Unie van Suid-Afrika as huidige staatseenheid neem en daarbinne die bestaan aantref van Blankes van tweeledige kultuurherkoms naas Kleurlinge, Indiërs en die verskillende Bantoevolke en daaruit een gemeenskaplike volkseenheid deur samegroeiing wil laat ontplooi, beteken dit kortweg dat die bestaande Blanke en Bantoevolkseenhede soos by 'n kernreaksie gesplits moet word en tot 'n nuwe element moet verbind. Die inisiatief vir hierdie optrede sal vanweë sy beherende posisie van die Blanke eenheid moet uitgaan. Daar sal die bereidwilligheid tot selfvernietiging as volkseenheid moet bestaan. Die feit dat dit nie bestaan nie, dat daar die strewe bestaan tot afsondering en suiwere bewaring van die westerse lewens- en godsdienstige erfenis, word deur die Tomlinson-kommissie as die kardinale feit in die SuidAfrikaanse situasie aangemerk.

As ons dan verder besef dat hier nie net een van die verswarende faktore by samegroeiing werksaam is nie maar al vyf, naamlik verskil in getalsterkte, verskil in kultuurstand, verskille op fisiese terrein, psigologiese faktore en geskiedkundige faktore, dan moet mens besef dat alleen ' $n$ dwaas ' $n$ voorspelling sal waag oor die termyn van generasies wat vir die volvoering van hierdie proses nodig sal wees. Dit vereis egter geen profetiese insig om te besef dat die afwerking van al vyf die verswarende faktore in Suid-Afrika die geweldigste chaos, die geweldigste wedersydse venyn, vyandskap en veragting sal veroorsaak nie. Niemand kan sê hoelank dit sal duur voordat die einde van hierdie maatskaplike wanorde en ordeloosheid sal aanbreek nie. Elkeen kan egter 'n denkbeeld vorm van die omvang van hierdie toestand van chaos waarop met sekerheid afgestuur sal word.

Wanneer daar dan in Suid-Afrika as alternatief vir hierdie periode van interne stryd, van afsonderlike ontwikkeling gepraat word, moet mens duidelik verstaan dat dit nie die hersensproduk van 'n paar mense is nie, maar die uitbouing van 'n toestand wat asof normaal oor 300 jaar onstaan het vanweë die besef van die onverbindbaarheid van mense en hulle lewenswyse. In hierdie sin moet mens die hand van die Skepper daarin aanvaar. Laat ons dan versigtig wees om met die energie-samestelling volkseenhede, waarvan ons baie min weet, te peuter. Die ontploffing kan katastrofaal in sy vernietigingskrag wees.

Binne die Suid-Afrikaanse verband is dit korrek om te sê dat die Blanke volkseenheid vir homself 'n eie voortbestaansreg opeis. Enige invloed wat dit bedreig sal afgeveg word. Uit 'n besef van regverdigheid en van verpligting om die Bantoevolke die Boodskap van Christus en die kennis van die Weste deelagtig te maak, is die Blanke volk bereid om aan die Bantoevolke elk binne sy eie vaderland dit te waarborg wat 
hy vir homself opeis, naamlik ontwikkeling in westerse rigting tot die hoogste sport waartoe die bekwaamheid bestaan.

Om hierdie rede val die klem in die ontwikkelingsproses tans nie net op verwestering nie maar ook op die behoud van die Volksidentiteit van elke Bantoevolk sowel as op die behoud van afsonderlike taaleenhede in plaas van die verskeurende werking van 'n Common Language. Hiernaas word die aanvang van ekonomiese ontwikkeling tesame met 'n proses van verstedeliking binne Bantoegebiede van stapel gestuur: ontwikkeling van tegniese insig tesame met die van die mensemateriaal met die behoud van waardegewende beginsels uit die tradisionele lewe. Wanneer die Blanke hierdie proses van stapel stuur moet hy in alle ootmoed besef dat alhoewel hy 'n einddoel mag stel, dit die Bantoevolke self sal wees wat die tempo van ontwikkeling tot op groot hoogte sal bepaal vanweë die werking van die proses van kultuurverandering. Een saak is egter op hierdie stadium reeds helder en dit is dat daar kwalik sprake kan wees van afsonderlike ontwikkeling vir die Bantoevolke sonder 'n samevoeging van hulle tuislande tot eenhede wat polities van betekenis sal wees. Daar sal die geleentheid tot vaderlandskonsolidering moet wees. Deur die aanvaarding van 'n proses van afsonderlike ontwikkeling het die Blankes hulle egter reeds by implikasie hiertoe verbind.

Dat ons in hierdie volledige proses met iets groter as blote ekonomiese ontwikkeling besig is, moet besef word. Dat die termyn wat vir kultuurverandering gevra word daarom langer sal wees as vir blote ekonomiese ontwikkeling hoort net so duidelik te wees.

Dit word egter vandag gesê dat Suid-Afrika in die lig van gebeure elders in Afrika nie die tyd sal vind vir die proses wat ons geskets het nie; dat invloede van buite, waarvan die belangrikste die opkomende onafhanklike Afrikastate is, die Blanke volk tot abdikasie sal dwing.

In hierdie verband moet ons deeglik besef dat ontwikkeling noordwaarts in Afrika slegs beperk is tot die politieke sy van die lewe. Die noodsaaklik omvorming van die res van die lewe vir die uitbouing van staatseenhede volgens westerse patroon vind nie plaas nie. Die probleme waarmee hierdie state sal moet worstel in die bereiking van 'n nuwe toestand van harmonie is selfs groter as binne die Bantoegebiede waarvoor Suid-Afrika verantwoordelikheid dra. Die termyn waarin die volle proses hom sal voltrek sal egter nie veel van die in die Unie verskil nie. Inteendeel, ons kan die onrus wat moet volg by die samegroeiing van interne verskille in taal en lewenswyse van miljoene mense binne grense wat Blanke veroweraars getrek het, nie onderskat nie. Ons kan die feit dat hierdie proses tussen die hamer en die aambeeld van Westerse en Kommunistiese wedywering voltrek sal word, ook nie uit die oog verloor nie. Hierdie twee verswarende faktore sal binne die Suid-Afrikaanse situasie die Bantoevolke onder ons beskerming vermoedelik gespaar bly.

Swart nasionalisme in Afrika is in sy wese anti-Blank. Dit.word gedra deur voertale wat van westerse oorsprong is. Dit beskou alle tegniese 
verbeteringswerke wat koloniserende moonthede ingestel het as onderdrukking. Dit is daarom na ons oordeel 'n stroming wat valselik die benaming nasionaal verkry het daar dit nie op inheemse volks- en taalverdeling gebou is nie. Ons beskou dit daarom as van verbygaande waarde. Die enigste langtermyn teenvoeter, die opwekking van 'n ware nasionale bewussyn, is die kweek van volkstrots by die onderskeie volke in Afrika. As dit ons doel in Suid-Afrika is, moet ons besef dat dit alleen moontlik is indien van die bestaande lewenswaardes uitgegaan word. As ons dit wil doen mag die tempo waarteen verwestering plaasvind nie neerkom op die voorgestelde vernietiging en destruksie van sosiale ordes bloot omdat dit 'n tydelike beperking plaas op die snelheid waarmee ekonomiese ontwikkeling kan vorder nie.

As ons in die vereiste van die kweek van volkstrots by ons Bantoevolke nie slaag nie lei ons 'n basiese nederlaag. Dan stuur ons op chaos af, op die vorming van 'n ordelose horde Bantoemense. Dan is die proses verder noord in Afrika ook hier te verwagte. Dan het ons reeds vir die kommunisme die basiese voorwaarde van sukses, naamlik wanorde, geskep. 'n Toestand van chaos word deur hulle as voorwaarde vir die vestiging van 'n kommunistiese regime gestel. Om hierdie rede moet ons, in die lig van die Afrika situasie, versigtig wees om nie dit op te breek wat die hoeksteen vorm van waaragtige ontwikkeling nie.

As dit dan die omvang is van en tydsverloop is wat nodig is vir 'n proses van afsonderlike ontwikkeling volgens die insig van die Volkekunde, moet ons daarby erken dat hierdie insig nie ver genoeg gaan nie. Die prosesse van verandering wat in Afrika en Suid-Afrika voltrek sal word, sal soos orals ter wêreld volgens die Raadsplan van God geskied. Hierdie Raadsplan is aan geen mens bekend nie. Ons glo egter dat dit $\mathrm{Hy}$ is wat volke ten aansien roep en die proses van hulle lewe bepaal. Ons weet dat ons die ontstaan en lewensvorm van die Afrikaanse volk uit Sy hand ontvang het. Dit pas ons dus om na ons gebrekkige kennis, wat $\mathrm{Hy}$ op sy fondament geplaas het, nie af te breek nie.

Vir die bewaring van hierdie eie identiteit te midde van Swart Afrika kan ons alleen die gedagte van afsonderlike ontwikkeling as 'n moontlikheid sien. Langs alle ander weë kan ons volksvernietiging voorspel. Daar bly dus slegs die leuse van die moderne Israelse volk oor, naamlik ein bereira - geen alternatief.

R. D. Coertze. 